УДК 378.04:316.61

https://doi.org/10.34142/24130060.2019.17.1.20

\title{
ПОНЯТТЯ ТА СУТНІСТЬ СОЦАЛЬНОЇ ІНКЛЮЗІї У СОЦІАЛЬНІЙ РОБОТІ
}

\author{
О.О. Стрельнікова, Н.О. Ссіна
}

Харківський національний педагогічний університет імені Г. С. Сковороди

У статті розглянуто поняття та сутність інклюзї у сучасному українському суспільстві. Наведено характеристику основних форм інклюзї, соиіальної та освітньої, в сучасній Україні. Основну увагу приділено поняттю та сутності соціальної інклюзї̈, а також здійснено порівняльний аналіз понять «інклюзія» та «інтеграція», з метою визначення спільних та відмінних рис даних процесів. 3 метою обтрунтування поняття та сутності сочіальної інклюзї̈ у сочіальній роботі проаналізовано та узагальнено підходи до визначення сочіального включення.

Ключові слова: інклюзія, сочіальна інклюзія, освітня інклюзія, сочіальна ексклюзія, соиіальна інклюзія у соичільній роботі.

\section{ПОНЯТИЕ И СУЩНОСТЬ СОЦИАЛЬНОЙ ИНКЛЮЗИИ В СОЦИАЛЬНОЙ РАБОТЕ}

\section{Е.А. Стрельникова, Н.А. Есина}

В статье рассмотрено понятие и сущность инклюзии в современном украинском обществе. Дана характеристика основных форм инклюзии, социальной и образовательной, в современной Украине. Основное внимание уделено понятию и сущности соџиальной инклюзии, а также осуществлен сравнительный анализ понятий «инклюзия» и «интеграчия», с иелью определения общих и отличительных черт данных процессов. С целью обоснования понятия и сущнооти сочиальной инклюзии в сочиальной работе проанализированы и обобщены подходы к определению сочиального включения.

Ключевые слова: инклюзия, сочиальная инклюзия, образовательная инклюзия, соичиальная эксклюзия, соџиальная инклюзия в соџиальной работе.

\section{CONCEPT AND ESSENCE OF SOCIAL INCLUSION IN SOCIAL WORK}

\section{O. Strelnikova, N. Yesina}

The present article is devoted to the problems of inclusion in modern Ukrainian society. The concept and essence of inclusion are studied from the point of view of the theory of social comprehension (of the essence of inclusive group), dynamics of social structure and social interactions. The inclusion is divided into social and educational forms according to the modern approaches to considering types of inclusion. The main forms of inclusion are analyzed from the point of view of pedagogical and social sciences. Special attention is given to the social inclusion in modern Ukrainian society. The comparative analysis of the categories «integration» and «inclusion» is carried out and the main common and distinctive features of these categories are determined in the article. It is said that social inclusion can be analyzed only in context of social exclusion, because they are both parts of the same social process. The potential of such 
further analysis are researched. The peculiarities of the process of social inclusion in modern Ukrainian society are analyzed. The main characteristics of social inclusion are described in the article on the basis of analysis of modern scientific literature. Special attention is given to the social inclusion in social work and social science. From the point of view of socio-pedagogical science social inclusion is analyzed as democratic action about comprehension somebody or the whole social group into some activity or cultural process. Social inclusion in modern Ukrainian society becomes social mechanism, some kind of an instrument, aimed at overcoming the barriers and constraints on the path to social well-being, which radically changes the existing state social politics. The results of the research are used in the social work, pedagogical and social sciences.

Key words: inclusion, social inclusion, educational inclusion, social exclusion, social inclusion in social work.

Постановка проблеми. Трансформаційні процеси, що відбуваються в сучасному українському суспільстві, обумовлюють наявність значних змін у соціальній, політичній та економічній сферах життєдіяльності тощо. Останнім часом суттєвих перетворень зазнала й галузь освіти, що засновує процес набуття знань та навичок на принципах інклюзії. Така форма, відносно нова для сучасної України, спирається на положення деяких нормативно-правових актів, зокрема на Конституцію України, Національну доктрину розвитку освіти України у XXI столітті (2002), Концепцію розвитку інклюзивного навчання (2010), Указ Президента України «Про питання щодо забезпечення реалізації прав дітей в Україні» (2011) та Закон України «Про внесення змін до деяких законодавчих актів щодо доступу осіб з особливими освітніми потребами до освітніх послуг» (2018). Реалізація міжнародних та вітчизняних норм та стандартів актуалізує потребу наукового дослідження інклюзії, зокрема соціальної та освітньої, особливостей впровадження іiї засад на теренах сучасного українського суспільства.

Аналіз актуальних досліджень. Дослідження процесу інклюзії досить активно проводилося у межах психологічної, соціально-педагогічної та медичної галузей наукового знання. Окремі аспекти зазначеної проблеми були висвітлені й у межах соціології, однак недостатньою залишається кількість праць, що присвячено вивченню специфіки, умов та механізмів перебігу даного процесу. Це й обумовило актуальність всебічного 
соціологічного аналізу особливостей процесу інклюзії у сучасному українському суспільстві.

Окремі теоретичні та практичні положення, плідні для подальшого дослідження особливостей процесу інклюзії, наявні ще в роботах класиків соціології, зокрема у П. Бергера, Г. Гарфінкеля, Е. Гіденса, Т. Лукмана, К. Маркса, Р. Мертона, П. Сорокіна, А. Шюця тощо. Сучасні українські вчені, серед яких Є. Головаха, О. Дікова-Фаворська, О. Злобіна, С. Катаєв, Н. Костенко, М. Наумова, О. Піронкова, Ю. Романенко, А. Ручка, Л. Скокова, В. Танчер, Л. Хижняк та ін., розглядали ціннісно-нормативні та інституційнонормативні особливості інклюзї й стигматизації.

Проблема включення під час процесу набуття знань та навичок привертала увагу вітчизняних педагогів, а саме Н. Софій, А. Колупаєвої, Ю. Найди (під час дослідження концептуальних аспектів інклюзивної освіти); А. Шевцова (під час обгрунтування освітніх засад реабілітології); О. Рассказової (щодо формування соціальності особистості в умовах інклюзивної освіти); В. Засенка, Н. Софій (під час надання характеристики сучасного стану та перспектив розвитку інклюзивної освіти в сучасній Україні) та ін. Незважаючи на значну кількість наукових праць із зазначеної проблематики, дослідження особливостей процесу інклюзії, обгрунтування понятійно-категоріального апарату, встановлення та характеристика його основних складових елементів й досі залишаються недостатньо висвітленими.

Отже, мета даної статті полягає у дослідженні поняття та сутності соціальної інклюзії в соціальній роботі в умовах сучасного українського суспільства.

Виклад основного матеріалу. Звертаючись до аналізу особливостей процесу інклюзії, варто зазначити, що на сьогодні досить розповсюдженою практикою є використання понять «інклюзія» та «інтеграція» як тотожних. Незважаючи на той факт, що дійсно вони мають певні спільні риси, все ж таки між ними існують принципові відмінності. 
Поняття «інклюзія» здебільшого використовується в контексті інклюзивного навчання, під яким український законодавець розуміє «систему освітніх послуг, гарантованих державою, що базується на принципах недискримінації, врахування багатоманітності людини, ефективного залучення та включення до освітнього процесу всіх його учасників» (ЗУ «Про освіту», ст. 1, 2018). А, відповідно, під інклюзією розуміється політика та процес збільшення ступеня участі всіх громадян у всіх галузях суспільного життя, за умови врахування потреб та можливостей кожного. Поняття «інтеграція» не може бути тотожним інклюзї, оскільки охоплює лише певний етап даного процесу. На думку Н. Черненко, інтеграція передбачає пристосування до вже існуючої моделі, разом із всебічним сприянням такому пристосуванню, а інклюзія характеризується розумінням того, що всі члени суспільства належать до соціальної системи. Кожна людина являє собою частину соціальної системи, а тому елементи оточення повинні бути заздалегідь готовими до існування осіб з різними здібностям та потребами (2013, с. 3). Отже, інклюзія становить собою ширше за змістом поняття, ніж інтеграція, котра характеризує лише певний складовий елемент «включення» - введення до соціального простору; етап розвитку системи, пов язаний із переосмисленням суспільством і державою ставлення до осіб з особливими потребами, 3 визнанням їхнього права на одержання рівних 3 іншими можливостей в різних галузях життя (Колупаєва, 2012, с. 169).

У цілому погоджуючись із думкою сучасних дослідників щодо диференціації понять, наголосимо на тому, що інтеграція має суттєве обмеження - вона не передбачає впровадження змін в організацію соціальної системи. «Перебудова соціального середовища та суспільної свідомості, потрібна для інклюзї людей з особливими потребами, відрізняє цей процес від інтеграції, породженої концепцією нормалізації - ідеї про те, що життя й побут людей 3 обмеженнями життєдіяльності мають максимально наближатися до умов і стилю життя суспільства» (Шевцов, 2009, с. 22). 
У межах сучасної соціологічної науки, як вітчизняної, так і зарубіжної, досі не запропоновано однозначного трактування концепту «соціальної інклюзії» чи «соціального включення». П. Штомпка визначає сутність соціальної інклюзії (включення) через розуміння інклюзивної групи. Він розрізняє групи ексклюзивні, елітарні, приналежність до котрих обумовлена жорсткими вимогами, правилами та особливими принципами вступу, й інклюзивні, відкриті, легкодоступні, що не мають чітких обмежень до входження. До останніх можна віднести професійні групи, громади, спільноти та об’єднання людей, які мешкають на спільній території, як правило, знаходяться в особистісному контакті та здійснюють певну діяльність, що є проявом їхньої суспільної активності. Приналежність до інклюзивної групи становить один 3 найважливіших елементів індивідуальної ідентичності людини (2005, с. 215-237).

Багато сучасних науковців наголошують на нерозривному зв’язку концептів «соціального включення» та «соціального відторгнення» як на двох основних взаємопов'язаних частинах одного й того ж соціального явища. Спираючись на уявлення Н. Лумана про соціальну ексклюзію як негативну форму соціального включення, Т. Попова зазначає, що соціальній інклюзії повинно протиставлятися соціальне відторгнення, а розгляд цих понять поодинці $\epsilon$ неможливим та некоректним $(2013$, с. 4). В цілому погоджуючись 3 М. Астоянц та I. Россихіною, дослідниця наголошує, що «визначаючи деяким чином фактори соціальної ексклюзії, ми тим самим визначаємо спрямованість наших подальших дій щодо боротьби із соціальним виключенням шляхом впливу саме на ці чинники i, отже, намічаємо шляхи соціальної інклюзії відповідно до цього визначення» (Попова, 2013, с. 4).

В. Ярська, звертаючись до проблеми визначення соціальної інклюзії, зазначає, що включення має на увазі певний прояв бажання залучити індивіда чи групу до ширшої спільноти 3 метою приєднатися до спільної діяльності чи культурного процесу. Соціальна інклюзія є необхідною умовою 
задля подолання нерівності, набуття свободи та нової якості життя (2008, с. 11). На думку Л. Солдатової, соціальна інклюзія становить собою «процес, що передбачає сукупність регулюючих заходів та самоорганізації суспільства, спрямований на підвищення ступеня активної участі в житті суспільства індивідів або груп із всіма особливостями їхніх демографічних, економічних, політичних і культурнодуховних характеристик» (2010, с. 105).

У сучасній науковій думці існують спроби використання концепту «соціальної інклюзії» задля пояснення динаміки соціальної структури та аналізу соціальних взаємодій. Зокрема, С. Бабенко звертає увагу на двоїстий механізм включення: 3 одного боку, відкривається доступ до ресурсів, а 3 другого, через ексклюзію забезпечуються розмежування соціальних груп із нерівними можливостями. Авторка зазначає, що інклюзія - ексклюзія являє собою невід’ємний аспект у відтворенні, закріпленні та сприйнятті структур соціальної нерівності (2007, с. 49-52).

Виходячи 3 положень теоретичної концепції П. Сорокіна, можливо стверджувати, що соціальна інклюзія може відбуватися у два способи: поперше, за умови підвищення соціального статусу, що дозволить особі або групі осіб більшою мірою впливати на усі аспекти життя громади чи суспільства в цілому; чи по-друге, через повернення особи або групи осіб до загальновизнаної соціальної ієрархії (Попова, 2013, с.3-5). Що у свою чергу й обумовлює складність соціального включення. Адже визначена соціальна група реалізовує певний опір щодо входження до неї нових членів через так звані «соціальні бар’єри» (обмеження). Чинниками такого обмеження можуть виступати гроші (або їхня кількість), рівень культури та освіти, набуті професійні навички, спосіб та стиль життя тощо. Для успішного подолання обмежень замало лише бажання, необхідною умовою стає наявність ресурсів та готовність до усунення (здолання) бар’єрів (Попова, 2013, с.3-5).

На сьогодні найпоширенішою у сучасному науковому дискурсі стає спроба пояснити концепт «соціальної інклюзії» через доступність освіти для усіх громадян України. В даному випадку соціальна інклюзія практично 
зводиться до інклюзії освітньої. На думку А. Колупаєвої, включення до системи соціальних стосунків та взаємодій, перш за все, відбувається в рамках того освітнього середовища, до котрого особа чи група осіб намагається долучитися (2009, с. 18). Окреслюючи шляхи включення, дослідниця звертає увагу на те, що «окрім підготовки такої особи до життя в суспільстві, ще й необхідна підготовка суспільства до прийняття особи. Одним із найважливіших факторів соціальної інклюзії $\epsilon$ формування відповідних правових основ держави, що регламентують сприятливі умови для формування позитивних стосунків між усіма членами суспільства, а також передбачають вплив суспільства i соціального середовища на особистість та активну участь у цьому процесі самої особистості» (Колупаєва, 2012, с. 9).

Так, Л. Міщик вважає, що соціальна інклюзія - це процес збільшення ступеня участі всіх дітей у соціальному житті та різних програмах (2012, c. 57).

Н. Кліменюк відзначає, що на емпіричному рівні доведено, що інклюзія в освіті дає можливість усім, хто бажає навчатися, повною мірою брати участь у житті колективу - починаючи від дошкільного і завершуючи вищим навчальним закладом; інклюзія володіє ресурсами, спрямованими на встановлення рівноправ’я спілкування та максимальної соціалізації всіх, хто навчається (2009, с. 148-153).

Останнім часом інклюзію розглядають ширше, ніж просто забезпечення прав людини на освіту. Національна асамблея інвалідів України, зазначає, що інклюзія - це політика і процес, які забезпечують повну участь усім членам суспільства в усіх сферах життєдіяльності (Національна Асамблея Інвалідів України, 2018, с. 306).

Висновки i перспективи подальших досліджень. Сучасне суспільство визнає, що саме інклюзія є більш гуманною та ефективною освітньою системою, яка здатна задовольнити потреби всіх категорій дітей, незалежно від рівня психофізичного розвитку, та сприяє створенню 
інклюзивного суспільства, яке б повною мірою сприймало таких учнів, визнавало їхні права на освіту, особистісний розвиток, професійну діяльність, участь у суспільному житті.

У соціально-педагогічному аспекті соціальну інклюзію розглядають як демократичну акцію включення індивіда чи певної групи людей до більшої спільноти для залучення до діяльності чи культурного процесу (ЯрськаСмирнова, 2005, с. 51). Як правило, об’єктом соціальної інклюзії виступає не лише індивід чи група, але й сім’я та соціальне оточення, які впливають на прийняття рішень, спілкування, розв'язання складних життєвих завдань, нормалізацію життєдіяльності і відпочинку кожної людини чи групи в цілому, взаємодію з оточуючим середовищем, допомагають у раціональному вирішенні складних ситуацій, конфліктів. Поняття соціальної інклюзії поступово стає темою соціально-педагогічної дискусії.

Отже, соціальна інклюзія в сучасному українському суспільстві стає певним соціальним механізмом, інструментом, спрямованим на подолання бар’єрів та обмежень на шляху до соціального благополуччя та добробуту, що докорінно змінює існуючу державну соціальну політику. Власне, соціальне включення можна визначити як бажану ситуацію, у межах котрої всі члени суспільства володіють достатніми ресурсами та можливостями задля повноцінної та рівноправної участі в усіх сферах суспільної діяльності. Соціальна інклюзія торкається усіх соціальних процесів й фактично сприяє утвердженню у суспільстві соціальної рівності.

\section{ЛIТЕРАТУРА}

1. Астоянц, М.С. и Россихина, И.Г., 2009. Социальная инклюзия: попытка концептуализации и операционализации понятия. Изв. Юж. федеральн. ун-та. Педагогические науки, 12, с. 51-58.

2. Бабенко, С.С., 2007. Социальная включенность и социальная эксклюзия: новое измерение социальных неравенств в современном обществе. Методологія, теорія $i$ практика соціологічного аналізу сучасного суспільства : зб. наук. пр., с. 49-55.

3. Відомості Верховної Ради, 2018. Закон України «Про освіту». [online] Доступно: https://zakon.rada.gov.ua/laws/show/2145-19 [Дата звернення 05 лютий 2019].

4. І Ільченко, Н. та Жиленко, Р., 2006. Соціальне включення: теорія і практика. Екон. розвиток громади, 2, с. 2-6. 
5. Клименюк, Н.В., 2009. Інклюзія людей з особливими потребами до суспільного життя: історичний аспект. Наукові пращі Чорноморського державного ун-ту імені Петра Могили «Києво-Могилянська академія», 99, с. 148-153.

6. Колупаєва, А.А. ред., 2012. Основи інклюзивної освіти. Київ: А. С. К.

7. Міщик, Л., 2012. Інклюзивна освіта як умова сочіалізації дітей-інвалідів у процесі навчання [online] Доступно: http://www.nbuv.gov.ua/portal/soc_gum/Znpkhist/2012_5/12mliupn.pdf [Дата звернення 05 лютий 2019].

8. Національна Асамблея Інвалідів України, 2018. Через освіту до соиіальної інтеграціï та інклюзіï. [online] Доступно: http://naiu.org.ua [Дата звернення 05 лютий 2019].

9. Попова, Т.Л., 2013. Соціальне залучення: концептуальні підходи до визначення. [online] Доступно: http://academy.gov.ua/ej/ej17/PDF/16.pdf [Дата звернення 05 лютий 2019].

10. Рєвнівцева, О.В., 2008. Соціальне виключення: проблеми визначення та дослідження. Демографія та сои. Економіка, 1, с. 98-106.

11. Савельєв, Ю., 2012. Суперечності концепції соціального виключення і включення: вплив соціально-політичного дискурсу на соціологічні теорії. Вісн. Київ. нац. ун-ту ім. Т. Шевченка, 3, с. 33-41.

12. Солдатова, Л.А., 2010. Роль социальной инклюзии в развитии общества. Труд $u$ социальные отношения, 4, с. 101-105.

13. Черненко, Н.M., 2013. Інклюзія в Україні: реалії сьогодення. SCIENTIFIC RESEARCH AND THEIR PRACTICAL APPLICATION. MODERN STATE AND WAYS OF DEVELOPMENT, c.161-168.

14. Шевцов, А.Г. 2009. Освітні основи реабілітології. Київ: МП Леся.

15. Штомпка, П., 2005. Сочиология. Анализ современного общества. Перевод с польского С. М. Червонной. Москва: Логос.

16. Ярская, В.Н. 2008. Инклюзия - новый код социального равенства. Образование для всех: политика и практика инклюзии: сб. науч. ст. и науч.-метод. материалов.

17. Ярская-Смирнова, Е.Р. и Романов, П.В. 2005. Проблема доступности высшего образования для инвалидов. СОЦИС, 10, с. 48-54.

\section{Інформація про автора}

Стрельнікова Олена Олександрівна - кандидат соціологічних наук, старший викладач кафедри політології, соціології і культурології Харківського національного педагогічного університету імені Г.С. Сковороди; e-mail: elenastrelnikova85@gmail.com; ORCID: https://orcid.org/0000-0003-2042-7186.

Єсіна Наталія Олександрівна - кандидат педагогічнихнаук, доцент, доцент кафедри соціальної педагогіки Харківського національного педагогічного університету імені Г.С. Сковороди; e-mail: bav_1976@ukr.net; ORCID: https://orcid.org/0000-0001-9546-418x.

Стаття надійшла до редакції: 07.02.2019 р. $\quad$ Прийнята до друку: 18.02.2019 p. 